\title{
Evaluation of Urban Land Comprehensive Carrying Capacity in Xi'an City Under the Process of Urbanization
}

\author{
Yusi Teng ${ }^{1,2, *}$ and Weili Xia ${ }^{1}$ \\ ${ }^{I}$ School of Management, Northwestern Polytechnical University, No. 127 Youyi West Road, Xi'an, P.R. China; ${ }^{2}$ Faculty \\ of Humanities and Foreign Languages, Xi'an University of Technology, No. 5 Jinhua South Road, Xi'an, P.R. China
}

\begin{abstract}
This paper attempts to establish an evaluating index system of land comprehensive carrying capacity in Xi'an city involving three aspects, such as economic carrying capacity, social carrying capacity, and ecological carrying capacity, combined with the development goals and constraint factors of Xi'an city. Furthermore, the method of mean-squared deviation weight decision is adopted to evaluate the status and dynamic change of land comprehensive carrying capacity in Xi'an City under the process of urbanization. As the results indicate, the index of land comprehensive carrying capacity in Xi'an city shows an overall upward trend with a low starting point between 2001 and 2012. The index of land comprehensive carrying capacity in Xi'an city was at a high level in 2012, while that of ecological carrying capacity was at a low state with only 0.3521 . Therefore, with the development of urbanization, it is significant to improve urban ecological environment, and then to strengthen rational planning and adjustment of land use for enhancing land comprehensive carrying capacity, as well as for realizing sustainable urban development of Xi'an city in the future.
\end{abstract}

Keywords: Urban land, Comprehensive carrying capacity, Urbanization, Xi'an city, Economic carrying capacity, Social carrying capacity, Ecological carrying capacity.

\section{INTRODUCTION}

Urbanization refers to the historical transformation of production mode and lifestyle of the humanity from the rural type to the urban type $[1,2]$. Urbanization process that involves all aspects of human life has attracted great concern of scholars. Recently, problems generated by the urbanization process, such as evaluation of urban land comprehensive carrying capacity in the urbanization process, have become an important study issue in the current academics. Urban land comprehensive carrying capacity can be defined as a capacity limit for land resources to carry a variety of economic and social activities in a given period, a given region, and in some relatively stable environment, scientific technology and socio-economic development conditions [3]. Evaluation of urban land comprehensive carrying capacity plays a significant role in reflection, instruction and guidance for the urban development prospect. Therefore, with the rapid development of urbanization process, it is necessary to study urban land comprehensive carrying capacity for improving the efficiency and exploring the potential of urban land use, as well as for protecting the sustainable use of land resources.

Xi'an is not only an important central city in the western region of China, but also a new starting point and a bridgehead of the Silk Road economic zone [4]. In recent years, the land comprehensive carrying capacity of Xi'an has

*Address correspondence to this author at the Xi'an University of Technology, Yanxiang Road 58., P.O. Box 1155, 710054 Xi'an, P.R. China; Tel: +86-29-62660266; E-mail: rainy009@msn.com increasingly confronted a severe challenge due to rapid urbanization and economic development, expansion of urban construction as well as the scale of urban population.

Whether the capacities of population and economy adapt to the threshold that land resources carry has become a significant prerequisite for the future sustainable development in Xi'an. Currently, researches on carrying capacity of regional land primarily are emphasized on single factor carrying capacity rather than on comprehensive carrying capacity, and thus the state of the regional carrying capacity cannot be fully reflected. In this paper, the fundamental factors, such as ecological environment, economic factors and social factors, are taken as the object of the study. The comprehensive assessment method is adopted to evaluate and analyze the situation and dynamic change of land comprehensive carrying capacity in Xi'an city between 2001 and 2012, in order to provide a feasible reference for the future land use and sustainable development of Xi'an city.

\section{OVERVIEW OF STUDY AREA AND DATA RE- SOURCES}

\subsection{Overview of Study Area}

Xi'an, also known as Chang'an, the capital of Shaanxi Province in China, is from North to South about 116 kilometers long and from West to East $204 \mathrm{~km}$ wide, located in the center of China's geographic territory, and in the middle of the plain of the Yellow River Basin. Till the end of 2012, 9 districts and 4 counties were under the jurisdiction of 
the city, which covers a total area of about 10,108 square kilometers including the urban area of about 3852 square kilometers. The total population of the city amounts to 8.06 million. GDP has reached 488.41 billion Yuan, of which the primary industry, secondary industry and tertiary industry respectively account for $4.5 \%, 43.3 \%$, and $52.2 \%$ respectively. In 2013, the amount of total land resources in Xi'an was $1,009,680.65 \mathrm{hm}^{2}$, involving $830,358.41 \mathrm{hm}^{2}$ agricultural land resources, which accounted for $82.24 \%$ of the total area of city; construction land was $155,574.90 \mathrm{hm}^{2}$, accounting for $15.41 \%$; unused land was $23,744.74 \mathrm{hm}^{2}$ with the proportion of $2.35 \%$. Xi'an not only has the largest population, more economic aggregate and higher degree of modernization in the Northwest of China, but also has become an important transport hub in the Northwest [5].

\subsection{Data Resources}

The data of this paper is mainly from the "Xi'an Statistical Yearbook 2014" [5], "China City Statistical Yearbook (2002-2013)" [6], "China Urban Construction Statistics Yearbook 2013" [7] and "China statistical Yearbook 2013" [8]. Some data, which cannot be acquired from the Statistical Yearbooks and other documents, is calculated by a linear regression model.

\section{ESTABLISHMENT OF EVALUATION INDEX SYSTEM}

\subsection{Establishment Principles of Evaluation Index System}

Through evaluating urban land comprehensive carrying capacity, not only the capacity of land resources, which is able to carry the natural, economic and social subsystems within the given region, but also the extent of development and coordination between each subsystems could be fully and accurately measured. To achieve this goal, following principles must be obeyed in the design and selection of evaluation index system $[9,10]$ :

Firstly, system coordination principle should be obeyed. Land comprehensive carrying capacity is regarded as a comprehensive capacity of land resources to carry several factors of ecological environment, economic and social development. Hence, mutual restraint and interaction between subsystems of the evaluation index system should be systematically handled with multi-perspectives.

Secondly, the combination principle of geographical similarity and distinction should be emphasized. The similarity and the uniqueness of the given region should be taken into account at the same time to select study indicators of urban land comprehensive carrying capacity. Furthermore, characteristics and functions of study area should be fully considered to highlight the effects of land carrying capacity for the design of evaluation index system.

Thirdly, the system of land comprehensive carrying capacity is a complex system composed by a number of factors, thus, its evaluation index system should also represent corresponding layers.

Fourthly, not only the data can be easily collected, but also the authenticity and usability of statistics should be ensured for building an evaluation index system of land com- prehensive carrying capacity in order to achieve the practical significance and operability of the evaluation index system.

\subsection{Establishment of Evaluation Index System}

In this paper, according to the concept of land comprehensive carrying capacity and design principles of its evaluation index system above [11-13], additionally combined with characteristics of study area, the capacity of land resources for ecological environment and socio-economic development is focused on. Therefore, the indicators in three areas mentioned above are selected to establish an evaluation index system of land comprehensive carrying capacity in Xi'an city, including three parts: ecological carrying capacity, economic carrying capacity and social carrying capacity (see Table 1).

By calculating the ratio of indicators of various subsystems and their corresponding standard values, the capacity values of each indicator which are carried by land resources in a certain area, can be measured. The formula is as follows:

$x_{i}=\frac{c_{i}}{s c_{i}}(i=1,2, \ldots, n)$

In the formula1, $x_{i}$ indicates the carrying capacity index of land resources for the indicator of item $i$ within a certain area, $c_{i}$ refers to the indicator of item $i, s c_{i}$ is the corresponding standard value of the indicator of the item $i$.

\subsection{Determination of Standard Values in Evaluation In- dex System}

Since the land comprehensive carrying capacity indexes need to calculate the ratio of the selected indicators and standard values, it is essential to determine the standard value of each indicator, which directly influences the scientific nature and rationality of evaluation results. In this paper, the standard value of each indicator is determined by the characteristics of different indicators.

For instance, per capita arable land, the world average cultivated land area per capita refers to the present average level of cultivated land resources used by humans. China cultivated land area per capita, which is far less than the world average level, is one of the least cultivated land area countries. Thus, it is better to use the world average value of cultivated land area per capita than the national average value. Moreover, Xi'an is attached to the mega-cities in China [14]. Hence, the public green land area per capita should be compared with domestic and foreign cities at the same level. In addition, because the public green land areas of Chinese mega-cities are generally smaller than that of other international metropolis, it is more reasonable to choose the average value of typical mega-cities in developed countries as the standard value. Other indicators also follow this criterion $[5-8,15,16]$, which can be seen in Table 1.

\subsubsection{Standardization of Evaluation Index}

The evaluation of land comprehensive carrying capacity involves several factors, such as ecological environment, socio-economic development and other factors, which have 
Table 1. Evaluation index system of land comprehensive carrying capacity in Xi'an city.

\begin{tabular}{|c|c|c|c|c|c|c|}
\hline $\begin{array}{l}\text { Target } \\
\text { layer }\end{array}$ & Criteria layer & Index layer & Index calculation & Property & $\begin{array}{l}\text { Standard determina- } \\
\text { tion }\end{array}$ & $\begin{array}{l}\text { Standard } \\
\text { value }\end{array}$ \\
\hline \multirow{14}{*}{ 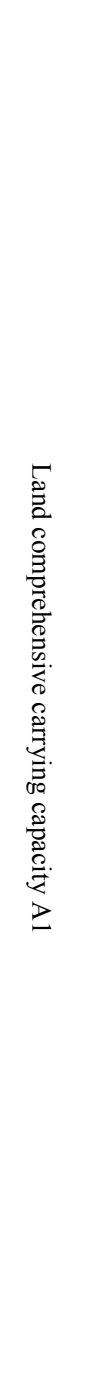 } & \multirow{5}{*}{$\begin{array}{l}\text { Carrying capacity of } \\
\text { ecological environment } \\
\text { B1 }\end{array}$} & $\begin{array}{l}\text { water resource per capita } \\
\qquad(\mathrm{m} 3 / \mathrm{ppl} .) \mathrm{C} 1\end{array}$ & $\begin{array}{l}\text { total water resource/ total } \\
\text { population }\end{array}$ & benefit & national average level & 2000 \\
\hline & & $\begin{array}{l}\text { water consumption per } \\
\text { capita (m3 / ppl.) C2 }\end{array}$ & $\begin{array}{l}\text { total water consumption/total } \\
\text { population }\end{array}$ & benefit & $\begin{array}{l}\text { average level of simi- } \\
\text { lar cities }\end{array}$ & 400 \\
\hline & & $\begin{array}{l}\text { public green land area per } \\
\text { capita (m2 / ppl.) C3 }\end{array}$ & $\begin{array}{l}\text { public green land area / non- } \\
\text { agricultural population }\end{array}$ & benefit & $\begin{array}{l}\text { average level of de- } \\
\text { veloped countries }\end{array}$ & 15 \\
\hline & & $\begin{array}{l}\text { cultivated land area per } \\
\text { capita (hm2 /ppl.) C4 }\end{array}$ & $\begin{array}{l}\text { cultivated land ar- } \\
\text { ea/agricultural population }\end{array}$ & benefit & $\begin{array}{c}\text { international average } \\
\text { level }\end{array}$ & 0.26 \\
\hline & & $\begin{array}{l}\text { water consumption per 10k } \\
\text { Yuan GDP (m3 / } 10 \mathrm{k} \mathrm{Yu-} \\
\text { an) C5 }\end{array}$ & water consumption/GDP & cost & $\begin{array}{c}\text { international average } \\
\text { level }\end{array}$ & 120 \\
\hline & \multirow{4}{*}{$\begin{array}{l}\text { Economic carrying capac- } \\
\text { ity B2 }\end{array}$} & $\begin{array}{l}\text { GDP per capita (Yuan/ } \\
\text { ppl) C6 }\end{array}$ & $\begin{array}{l}\text { GDP / total permanent resi- } \\
\text { dent population }\end{array}$ & benefit & $\begin{array}{l}\text { standard level of de- } \\
\text { veloped countries }\end{array}$ & $300 \mathrm{k}$ \\
\hline & & $\begin{array}{l}\text { GDP of construction in- } \\
\text { dustry (100 mil. Yuan) C7 }\end{array}$ & statistic data & benefit & $\begin{array}{l}\text { average level of simi- } \\
\text { lar cities }\end{array}$ & 2000 \\
\hline & & $\begin{array}{l}\text { GDP of tertiary industry } \\
\text { (100 mil. Yuan) C } 8\end{array}$ & statistic data & benefit & $\begin{array}{l}\text { average level of simi- } \\
\text { lar cities }\end{array}$ & $10 \mathrm{k}$ \\
\hline & & GDP (100 mil. Yuan) C9 & statistic data & benefit & $\begin{array}{l}\text { average level of simi- } \\
\text { lar cities }\end{array}$ & $20 \mathrm{k}$ \\
\hline & \multirow{5}{*}{$\begin{array}{l}\text { Social carrying capacity } \\
\text { B3 }\end{array}$} & $\begin{array}{l}\text { Population density } \\
\text { (ppl./km2) } \mathrm{C} 10\end{array}$ & $\begin{array}{l}\text { total population/ total land } \\
\text { area }\end{array}$ & cost & $\begin{array}{l}\text { average level of simi- } \\
\text { lar cities }\end{array}$ & 1000 \\
\hline & & $\begin{array}{l}\text { residential building area } \\
\text { per capita (m2 / ppl.) C11 }\end{array}$ & $\begin{array}{l}\text { residential building area/ } \\
\text { total population }\end{array}$ & benefit & $\begin{array}{l}\text { maximum of similar } \\
\text { cities }\end{array}$ & 100 \\
\hline & & $\begin{array}{l}\text { construction land area per } \\
\text { capita (hm2 / ppl.) C12 }\end{array}$ & $\begin{array}{l}\text { construction land area/ non- } \\
\text { agricultural population }\end{array}$ & benefit & $\begin{array}{l}\text { standard level of de- } \\
\text { veloped countries }\end{array}$ & 400 \\
\hline & & $\begin{array}{l}\text { Urbanization } \\
\text { rate }(\%) \quad \mathrm{C} 13 * 100 \%\end{array}$ & $\begin{array}{l}\text { nonagricultural population / } \\
\text { total population }\end{array}$ & benefit & $\begin{array}{l}\text { average level of de- } \\
\text { veloped countries }\end{array}$ & 75 \\
\hline & & $\begin{array}{l}\text { grain output per capita }(\mathrm{kg} \\
\text { / ppl.) C14 }\end{array}$ & $\begin{array}{l}\text { total yield of grain/ total } \\
\text { population }\end{array}$ & benefit & $\begin{array}{c}\text { international average } \\
\text { level }\end{array}$ & 400 \\
\hline
\end{tabular}

different units of measurement and are difficult to be assessed. Therefore, to eliminate the effects of different units on evaluation results, all indicators with different units must be converted into standardized indicators without any unit before the evaluation. Then all of the data are between $0-1$, in order to facilitate a consistent approach to evaluate. In this study, evaluation indicators are divided into two categories involving cost category and benefit category. The cost indicator refers to the property value of an indicator negatively correlated with carrying capacity, such as the water consumption per 10k yuan GDP; while the benefit indicator is viewed as the property value of an indicator positively correlated with carrying capacity, such as the GDP per capita. The method of maximum difference dormalization is adopted to standardize indicators, and then the unit of standardized indicators is converted into 1 . The formulas are as follows:

a. Standardized method of cost indicators:
$Z_{i j}=\frac{x_{j \max }-x_{i j}}{x_{j \max }-x_{j \min }}(i=1,2, \ldots, n ; j=1,2, \ldots, m)$

b. Standardized method of benefit indicators:

$Z_{i j}=\frac{x_{i j}-x_{j \min }}{x_{j \max }-x_{j \min }}(i=1,2, \ldots, n ; j=1,2, \ldots, m)$

In formulas 2 and $3, Z_{i j}$ indicates the standardized data; $x_{i j}$ is the original data; $x_{\text {jmax }}, x_{j \min }$ are respectively the maximum and minimum indicators of $G_{j}\left(G_{j}\right.$ refers to the collection of indicators of $j$ ).

\subsubsection{Determination of Evaluation Index Weights}

Currently, there are two main methods of index weighting including subjective weighting and objective weighting [17]. As for subjective weighting methods, such as 
Table 2. Index system weights of land comprehensive carrying capacity in Xi'an city.

\begin{tabular}{|c|c|c|}
\hline Criteria layer & Index layer & Weights \\
\hline \multirow{5}{*}{$\begin{array}{l}\text { Carrying capacity of ecological environment } \\
\qquad \text { B1 }\end{array}$} & Water resource per capita (m3 /ppl.) C1 & 0.1441 \\
\hline & Water consumption per capita (m3 /ppl.) C2 & 0.0512 \\
\hline & public green land area per capita (m2/ppl.) C3 & 0.3323 \\
\hline & cultivated land area per capita (hm2/ppl.) C4 & 0.0686 \\
\hline & water consumption of 10k Yuan GDP ( $\mathrm{m} 3 / 10 \mathrm{k}$ Yuan) C5 & 0.4038 \\
\hline \multirow{4}{*}{$\begin{array}{l}\text { Economic carrying capacity } \\
\qquad \text { B2 }\end{array}$} & GDP per capita (Yuan/ ppl) C6 & 0.2165 \\
\hline & GDP of construction industry (100 mil. Yuan) C7 & 0.2423 \\
\hline & GDP of tertiary industry (100 mil. Yuan) C8 & 0.3002 \\
\hline & GDP (100 mil. Yuan) C9 & 0.2410 \\
\hline \multirow{5}{*}{$\begin{array}{l}\text { Social carrying capacity } \\
\text { B3 }\end{array}$} & Population density (ppl./km2) $\mathrm{C} 10$ & 0.0452 \\
\hline & residential building area per capita (m2 / ppl.) C11 & 0.6441 \\
\hline & construction land area per capita (hm2 / ppl.) C12 & 0.1630 \\
\hline & Urbanization rate $(\%) \mathrm{C} 13 * 100 \%$ & 0.0568 \\
\hline & grain output per capita $(\mathrm{kg} / \mathrm{ppl}.) \mathrm{C} 14$ & 0.0910 \\
\hline
\end{tabular}

Delphi method, AHP, etc., index weight coefficient is mainly determined by the subjective experience of expert judgment. This method is used for a long time and is relatively mature but mainly depends on the observer's experience and is influenced much by subjective opinions. On the contrary, the objective weighting approaches involve principle component analysis, the mean square deviation method, etc., which do not rely on subjective judgment and are more accurate and reliable compared with subjective weighting methods. Some mathematical methods are used to determine the weights of indicators based on the relationship of the initial data. The mean square deviation weight decision, of which the concept and calculation methods are both easy to understand and to spread, is the most important and most commonly used method to reflect the discrete degree of random variables. In addition, the index weight coefficient calculated by this approach is more precise and more applicable to multi-index evaluation. In this paper, the mean square deviation weight decision is applied to the determination of the index weights and to the evaluation of land comprehensive carrying capacity in Xi'an city. The computation process is as follows:

At first, average values of random variables need to be calculated.

$$
E\left(G_{j}\right)=\frac{1}{n} \sum_{i=1}^{n} Z_{i j}
$$

Then mean square deviation values of indicators $G_{j}$ need to be worked out.

$$
\sigma\left(G_{j}\right)=\sqrt{\sum_{i=1}^{n}\left(Z_{i j}-E\left(G_{j}\right)\right)^{2}}
$$
ed.

Finally, the weight of each indicator needs to be calculat-

$$
W_{j}=\frac{\sigma\left(G_{j}\right)}{\sum_{j=1}^{m} \sigma\left(G_{j}\right)}
$$

\section{EVALUATION AND ANALYSIS OF THE RESULTS}

In accordance with the established evaluation index system, the land comprehensive carrying capacity of Xi'an city is assessed and analyzed. All indicators are primarily standardized by the formulas 2 and 3 . Then the standardized indicators are weighted by the formula 4,5 and 6 (see Table 2).

Finally, the linear weighted summation method is applied to multiple-index decision making and sorting to calculate carrying capacity of each index subsystem and land comprehensive carrying capacity index of Xi'an city, through $\mathrm{Y}_{\mathrm{i}}$ with the formula as follows:

$Y_{i}=\sum_{j=1}^{m} Z_{i j} W_{j}$

Scores in Table 3 are between $0-1$. The higher the score of carrying capacity index, the greater the capacity of land resources, which is able to carry a variety of human activities. If scores are higher than 0.6, which is set up as the standard score, it is indicated that the land comprehensive carrying capacity can meet the requirements of social, economic and ecological sustainable development and vice versa. 
Table 3. Classification evaluation criteria of urban land comprehensive carrying capacity.

\begin{tabular}{|c|c|c|c|c|c|c|}
\hline Score & $<0.2$ & $0.2 \sim 0.4$ & $0.4 \sim 0.6$ & 0.6 & $0.6 \sim 0.8$ & $>0.8$ \\
\hline Degree & lower & low & medium & normal & high \\
\hline
\end{tabular}

The weights of indicators in Table 2 are inserted into formula 7 to calculate the index of land comprehensive carrying capacity and carrying capacity indexes of each subsystem of Xi'an city in 2001-2012, which can be seen in (Fig. 1).

According to the calculation results mentioned above and classification standards in Table $\mathbf{3}$, the status of land comprehensive carrying capacity and carrying capacity of each subsystem of Xi'an city in 2012 can be clearly recognized: the index of land comprehensive carrying capacity was 0.6540 , which was at a high level and indicated that the land comprehensive carrying capacity can meet the requirements of social, economic and ecological sustainable development. Moreover, the indexes of economic and social carrying capacities were respectively 1 and 0.6095 being at a high level, while the index of ecological carrying capacity was at a low level with only 0.3527 , which showed that the land comprehensive carrying capacity can meet the needs of social, economic and ecological sustainable development. In future, the carrying capacity of land resources for ecological environment should be greatly improved by carrying out some appropriate measures (see Table 4).

From Fig. (1), a conclusion can be drawn that the index of land comprehensive carrying capacity in Xi'an city shows an overall upward trend with a low starting point between 2001 and 2012. The index has continuously raised from 0.1142 in 2001 to 0.6484 in 2008 . And then it reduced in the following two years until 2010 at the point of 0.5542 . In general, the indexes of land comprehensive carrying capacities in $\mathrm{Xi}$ 'an city ranging from 0.1142 to 0.3614 were relatively stable between 2001 and 2007; and there had been a leap of index change in 2008, which then stabilized at a range from 0.5542 to 0.6540 in 2008 2010. From the perspective of carrying capacity index changes of each subsystem, the development trend of ecological carrying capacity index closely approached that of

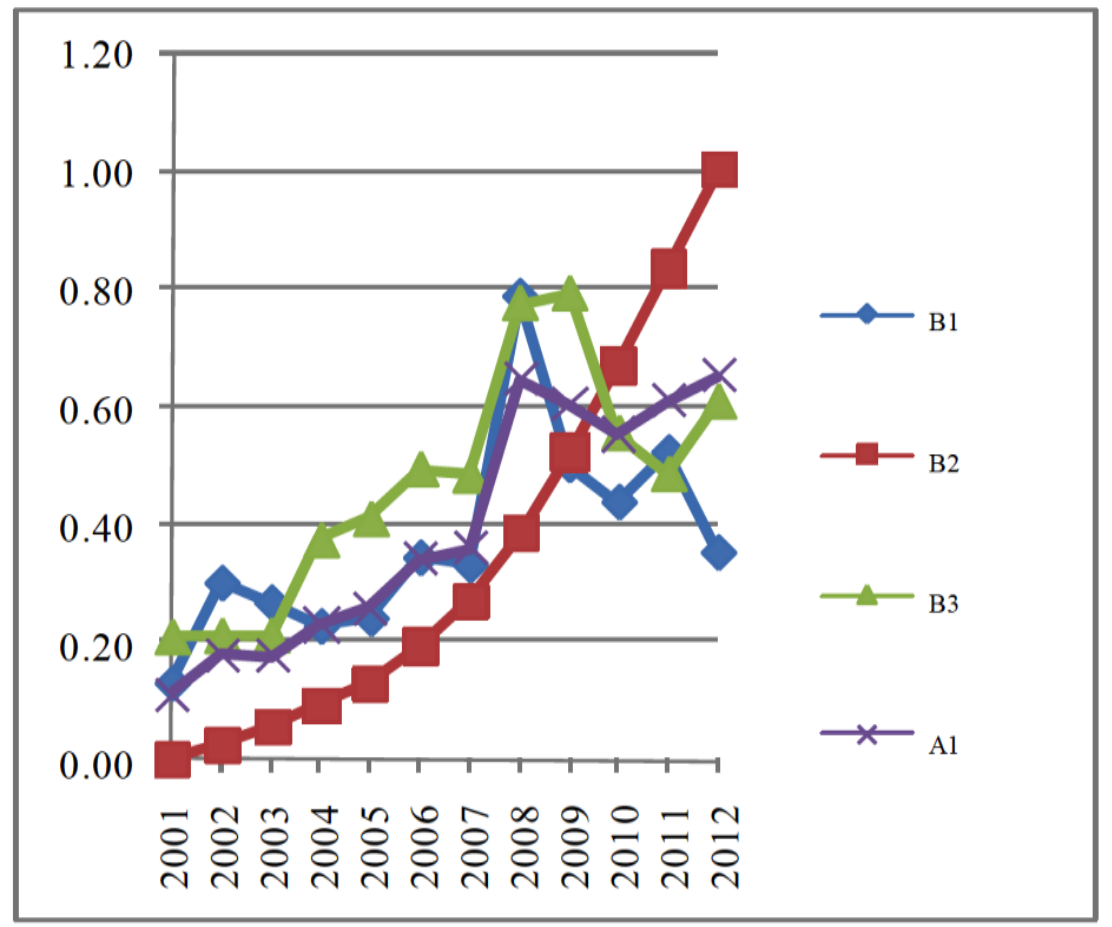

Fig. (1). Index change of land comprehensive carrying capacity and each subsystem carrying capacity of Xi'an city in 2001-2012.

Table 4. Evaluation results of land comprehensive carrying capacity of Xi'an city in 2012.

\begin{tabular}{|c|c|c|c|c|}
\hline Classification & A1 & B1 & B2 & B3 \\
\hline \hline Score & 0.6540 & 0.3527 & 1.0000 & 0.6095 \\
\hline Degree & high & low & higher & high \\
\hline
\end{tabular}


land comprehensive carrying capacity index in 2001, 2004-2007, and the differences of index were less than 0.03 . Both development trends in 2001-2011 were also very similar, but in 2012, the index of ecological carrying capacity had a larger decline. The indexes of social carrying capacity showed almost no change from 2001 to 2003, and were always around 0.21 . The fluctuation began in 2004, and there was a larger jump in 2008. Then it reached a maximum of 0.7923 in 2009 . However, it significantly dropped at 0.5562 in 2010 , but also recovered in the subsequent two years. The index of economic carrying capacity which kept an exponential increase, showed a steady upward trend despite of its lowest starting point. Until 2011, it exceeded 0.8 and accessed a higher level, which implied that economic carrying capacity was better than social carrying capacity and ecological carrying capacity in the current development of Xi'an city.

There was a sharp contrast between a steady rise of economic carrying capacity and a fluctuate advancement of social development and ecological carrying capacity, which resulted in a fluctuation of land comprehensive carrying capacity index of Xi'an city. To further enhance the land comprehensive carrying capacity, it is necessary not only to maintain the advantages of economic carrying capacity, but also to promote the rational and sustainable use of regional land planning and to improve the ecological carrying capacity of regional land by aiming at the coordinated development of economy, society and ecological environment. In addition, the investment in urban infrastructure and public facilities should also be increased. Employment opportunities and revenue should be created at the same time for promoting the development of social carrying capacity.

\section{CONCLUSION}

Urban land comprehensive carrying capacity can reflect the abilities of urban sustainability and healthy development. Researches on urban land comprehensive carrying capacity of cities in different areas with different urban functions focus on different aspects, but as a system, lack of any part of functions of land comprehensive carrying capacity can affect the operation of the whole system. Thus, on the basis of the current economic development and progress, geographical advantages, economic base and technological strength of Xi'an city should be fully utilized to further improve its potential resources and location, and to promote economic development, to create a new starting point of the Silk Road economic belt, as well as to enhance regional economic carrying capacity through technology innovation and development of culture, tourism and other industries. Meanwhile, in order to build an international metropolis oriented by the Silk Road economic belt, and to enhance regional social carrying capacity, the urban population size should be rationally regulated. Urbanization rate and employment opportunities should also be increased. Moreover, renovation and investment of urban infrastructure and municipal public facilities should be raised. In addition, the eco- logical environment carrying capacity in Xi'an city should also be strengthened by improving the urban ecological environment, intensifying the rational land use planning and regulation, increasing urban green space, forest and other ecological land area. Therefore, through the consolidation and enhancement of various carrying capacities, the urban land comprehensive carrying capacity can be ultimately improved, further protecting and realizing the sustainable development of Xi'an city in the future.

\section{CONFLICT OF INTEREST}

The authors confirm that this article content has no conflicts of interest.

\section{ACKNOWLEDGEMENTS}

This paper is supported by the Scientific Research Program Funded by Shaanxi Provincial Education Department (Program No. 13JZ086). The authors wish to thank the Department of Land and Resources of Shaanxi Province China for their help.

\section{REFERENCES}

[1] Y. Yang, Y. Gu, and H. Wei, "Analysis on correlation between Chinese urbanization process and employment growth," Research in Teaching, vol. 04, pp. 05-12, 2005.

[2] X. Jian, and K. Huang, "Empirical analysis and prospects prediction of China's urbanization level and speed," Economic Research Journal, vol. 03, pp. 28-39, 2010.

[3] Z. Guo, "Comprehensive evaluation of land resources carrying capacity in Beijing city," Urban Studies, vol. 15, no.5, pp. 24-30, 2008.

[4] C. Li, J. Sun, and X. Wang, 'Establishing Xi' an as the new starting point and the bridgehead of the Silk Road," Xi' an Daily, 2013.

[5] M. Zhang, "Xi'an Statistical Yearbook," China Statistic Press, Beijing, China, 2014.

[6] National Bureau of Statistics of PR. China: China Statistical Yearbook 2002-2013. China Statistic Press, Beijing, China, 2002-2013.

[7] Ministry of Housing and Urban-Rural Development of PR. China: China Urban Construction Statistics Yearbook 2013. China Planning Press, Beijing, China, 2013.

[8] Urban Social and Economic Survey Division of National Bureau of Statistics of PR. China: China City Statistical Yearbook (20022013), China Statistic Press, Beijing, China, 2013.

[9] S. Wang, and H. Mao, "Index system design and evaluation of land comprehensive carrying capacity - a case study of China's east coast," Journal of Natural Resources, vol. 16, no.3, pp. 248-254, 2001.

[10] S. Gong, "Principles of regional sustainable development," Geography and Territorial Research, vol. 15, no.1, pp. 1-6, 1999.

[11] X. Yue, and L. Song, "Review and Prospect of Land Carrying Capacity," Research of Soil and Water Conservation, vol. 15, no.1, pp. 254-257, 2008.

[12] Y. Song, R. Qi, and W. You, "Index system and method of ecocity," Urban Environment \& Urban Econogy, vol. 12, no.5, pp. 1619,1999

[13] X. Sheng, B. Peng, and H. Wang, "Research on index system of eco-city," Environment Herald, vol. 5, pp. 5-8, 2000.

[14] The State Council of PR. China: Announcement about Adjustment of the criteria for the classification of city size. 2014.

[15] Z. Lei, and H. Du, "Research on driven factors and model of China cultivated land area change," Journal of Anhui Agricultural Sciences, vol. 37, no. 22, pp. 10593-10595, 2009. 
[16] X. Song, O. Zhu, and L. Bai, "Development intensity and evolution stage of Chinese cultivated land resources," Scientia Geographic Sinica, vol. 33, no.2, pp. 135-142, 2013.
[17] M. Chen, D. Lu, and H. Zhang, "Comprehensive measurement and power factor analysis of Chinese urbanization," Acta Geographica Sinica, vol. 64, no.4, pp. 387-398, 2009.

Received: June 10, 2015

Revised: July 29, 2015

Accepted: August 15, 2015

(C) Teng and Xia; Licensee Bentham Open.

This is an open access article licensed under the terms of the (https://creativecommons.org/licenses/by/4.0/legalcode), which permits unrestricted, noncommercial use, distribution and reproduction in any medium, provided the work is properly cited. 